Review

\title{
The First Line of Defense: Receptor-like Protein Kinase-Mediated Stomatal Immunity
}

\author{
Zhe Wang and Xiaoping Gou *(D) \\ Ministry of Education Key Laboratory of Cell Activities and Stress Adaptations, School of Life Sciences, \\ Lanzhou University, Lanzhou 730000, China; wangzh13@lzu.edu.cn \\ * Correspondence: gouxp@lzu.edu.cn
}

\begin{abstract}
Stomata regulate gas and water exchange between the plant and external atmosphere, which are vital for photosynthesis and transpiration. Stomata are also the natural entrance for pathogens invading into the apoplast. Therefore, stomata play an important role in plants against pathogens. The pattern recognition receptors (PRRs) locate in guard cells to perceive pathogen/microbe-associated molecular patterns (PAMPs) and trigger a series of plant innate immune responses, including rapid closure of stomata to limit bacterial invasion, which is termed stomatal immunity. Many PRRs involved in stomatal immunity are plasma membrane-located receptor-like protein kinases (RLKs). This review focuses on the current research progress of RLK-mediated signaling pathways involved in stomatal immunity, and discusses questions that need to be addressed in future research.
\end{abstract}

Keywords: ABA; RLKs; ROS; signal transduction; stomatal immunity

check for updates

Citation: Wang, Z.; Gou, X. The First Line of Defense: Receptor-like Protein Kinase-Mediated Stomatal Immunity. Int. J. Mol. Sci. 2022, 23, 343. https://doi.org/10.3390/ ijms23010343

Academic Editor: Lars Matthias Voll

Received: 29 November 2021 Accepted: 27 December 2021 Published: 29 December 2021

Publisher's Note: MDPI stays neutral with regard to jurisdictional claims in published maps and institutional affiliations.

Copyright: () 2021 by the authors Licensee MDPI, Basel, Switzerland. This article is an open access article distributed under the terms and conditions of the Creative Commons Attribution (CC BY) license (https:// creativecommons.org/licenses/by/ $4.0 /)$.

\section{Introduction}

Guard cells are a kind of specialized kidney-shaped epidermal cells. The pore between a pair of guard cells is called a stoma, meaning mouth in Greek. Stomata exist in the epidermis of leaves, stems, petals, sepals, and other organs of most terrestrial plants. The term "stomata" in botany generally refers to the stomatal complex including two guard cells and the pore between them [1,2]. Stomata are channels for plants to exchange gas and water with the external atmosphere. Therefore, stomata play a key role during photosynthesis and transpiration in plants by regulating stomatal aperture to govern gas exchange ratio or water loss. Many environmental stimuli can induce stomatal movement, such as relative humidity [3], drought [4], $\mathrm{CO}_{2}$ concentration [5,6], and light [3]. Stomatal aperture is also regulated by plant hormones. For example, abscisic acid (ABA) regulates stomatal movement under drought conditions or bacteria invasion by inducing the production of reactive oxygen species (ROS) and a transient increase of cytosolic $\mathrm{Ca}^{2+}\left(\left[\mathrm{Ca}^{2+}\right]_{\text {cyt }}\right)$ in guard cells $[7,8]$. Salicylic acid (SA) regulates stomatal aperture by mediating ROS production in Arabidopsis (Arabidopsis thaliana) guard cells $[9,10]$. Methyl jasmonate (MeJA) can activate $\mathrm{Ca}^{2+}$ permeable cation channels in guard cells to close the stomata, which is similar to the mechanism of ABA-regulated stomatal closure [11,12].

When bacteria infect plants, they can survive on the plant surface and attach to stomata via their pili $[13,14]$. Numerous stomata are widely distributed on the epidermis, which therefore are the major way for the entry of bacteria. In the past two decades, researchers revealed that stomata are involved in plant innate immunity [15]. Pseudomonas syringae pv. tomato DC3000 (hereafter Pst DC3000) is a virulent pathogen of Arabidopsis and tomato (Solanum lycopersicum). Treatment with Pst DC3000 induces Arabidopsis stomatal closure, which can be reverted to the open state after the leaves are continuously treated with Pst DC3000 [15]. E. coli can trigger stomatal closure as well. However, continuous treatment with E. coli cannot re-open the stomata [15]. Therefore, although both plants and human bacteria can induce stomatal closure, Pst DC3000 acquired a specific mechanism during 
evolution to re-open stomata in order to facilitate more bacteria invading into the host plant. The phytotoxin coronatine (COR) is a well-characterized virulence factor of Pst DC3000. Lack of coronatine production reduces the toxicity of the mutant Pst bacteria [16], and the COR-deficient Pst DC3000 cor $^{-}$fails to re-open the closed stomata [15]. COR is considered as a structural mimic of JA conjugated to isoleucine (JA-Ile), and COR exhibits biological functions similar to JA-Ile [17]. COR is able to bind to the same receptor of JA to re-open the closed stomata induced by bacteria attack through the JA signaling pathway $[12,18]$ (Figure 1).
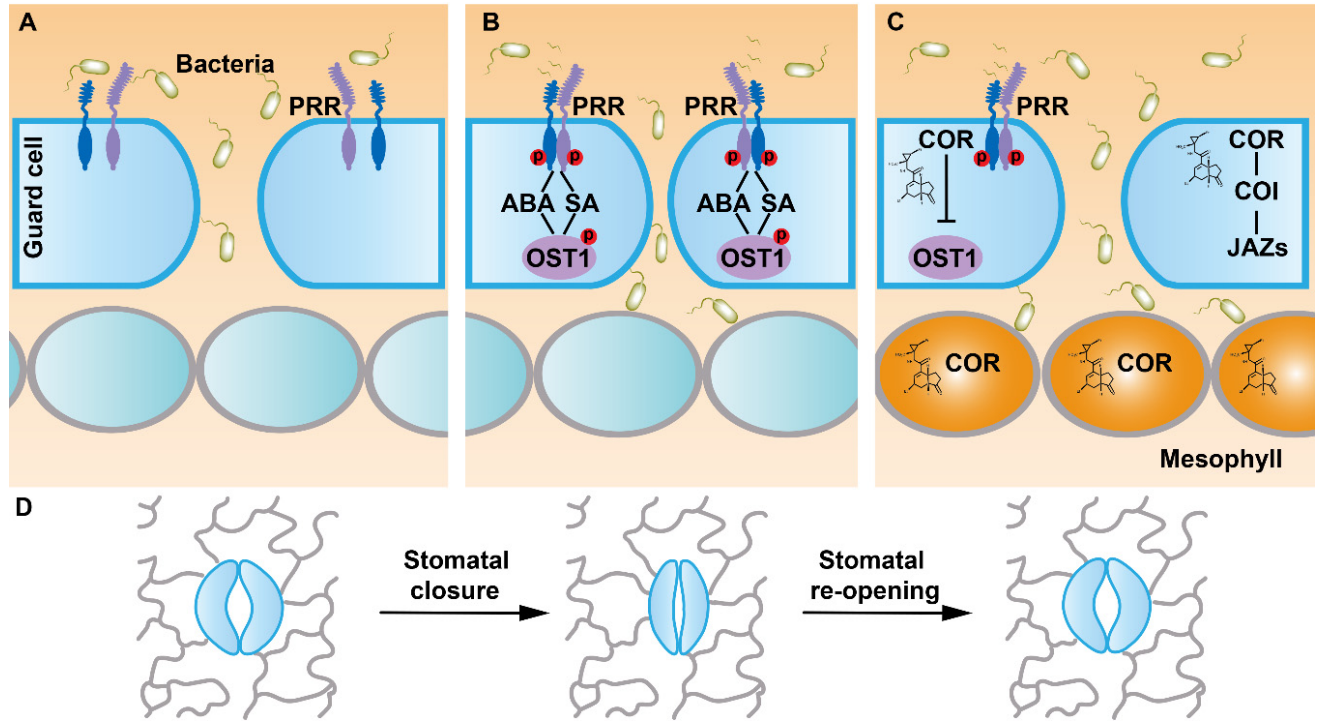

Figure 1. A general model of stomatal movement in plant defense against bacteria. The stomata are formed by two guard cells and the pore between them. The stomata are the main entry point of pathogen invasion. (A) When bacteria such as Pseudomonas syringae pv. tomato DC3000 (Pst DC3000) invade plants, pathogen-associated molecule patterns (PAMPs) can be sensed by membrane-localized pattern recognition receptors (PRRs) such as FLAGELLIN-SENSING 2 (FLS2). (B) FLS2 recruits its coreceptor BRI1-ASSOCIATED RECEPTOR KINASE 1 (BAK1) after perception of the PAMP to trigger rapid stomatal closure and limit bacterial invasion through ABA/SA signaling and a downstream kinase OPEN STOMATA 1 (OST1). (C) Pst DC3000 releases phytotoxin coronatine (COR) which is a structural mimic of JA conjugated to isoleucine (JA-Ile) to re-open stomata through the JA signaling pathway for more bacteria to infect plants. (D) A schematic diagram of stomatal movement during bacteria invasion.

The plant under bacterial infection can sense the bacterial molecules such as flg22 (a synthetic peptide of flagellin) and lipopolysaccharide (LPS), and close stomata to limit bacteria entry. These bacterial molecules were defined as pathogen/microbe-associated molecular patterns (PAMPs) [19-22]. PAMPs are recognized by the pattern recognition receptors (PRRs) that are plasma membrane-localized proteins with varied structures and functions. Most PRRs are plasma membrane-localized receptor-like protein kinases (RLKs) [21,23]. RLKs transduce extracellular signals into the cell to coordinate cellular activities during plant development and response to environmental stimuli [24-26]. In the past two decades, the functions of RLKs in plant immunity were extensively studied. For instance, FLAGELLIN-SENSING 2 (FLS2), a leucine-rich repeat (LRR) RLK, and its co-receptor BRI1-ASSOCIATED RECEPTOR KINASE 1 (BAK1) trigger plant innate immunity upon the perception of flg22 [27-29]. FERONIA (FER), a malectin-like receptor kinase, positively regulates plant immunity by destabilizing MYC2, a core transcription factor in the JA signaling pathway [30]. The LysM receptor kinase CHITIN ELICITOR RECEPTOR KINASE 1/LYSM DOMAIN RECEPTOR-LIKE KINASE 1 (CERK1/LYK1) and other LYKs form a PRR complex to sense chitin and regulate plant immunity against fungal 
infection [31-34]. Arabidopsis L-type lectin receptor-like protein kinase (LecRK) family contains 45 members, many of which were reported to regulate plant innate immunity by sensing various signals, such as extracellular purine molecules and PAMPs [35-37]. It is worth noting that lines of evidence suggested that these RLKs mediate signals to regulate stomatal movement during plant immunity. In this review, we discuss recent findings on stomatal immunity, mainly focusing on RLK-mediated signaling and the downstream regulators involved in this process.

\section{FLS2 Perceives Flg22 to Mediate Stomatal Immunity}

Different from animals, plants cannot move away from adverse environments as sessile organisms, which makes plants more vulnerable to microbial pathogens. Terrestrial plants have developed two interactive immune systems in response to pathogenic bacteria during the long-term evolution process: PAMP-triggered immunity (PTI) and effectortriggered immunity (ETI) [22]. Plant PTI responses usually depend on phosphorylation cascades to trigger downstream cellular events. For example, flg22 can trigger defense responses in Arabidopsis, including production of ROS, activation of mitogen-activated protein kinases (MAPKs), increased $\left[\mathrm{Ca}^{2+}\right]_{\mathrm{cyt}}$, and induced expression of immunity-related genes [15,38-41]. It has been well recognized that FLS2 functions as the receptor of flg22 to trigger plant PTI and downstream immune responses [42,43].

Perception of flg22 by FLS2 in Arabidopsis guard cells is necessary for bacteriumtriggered stomatal closure. The stomata could not be closed in the fls 2 mutants treated with flg22 [15]. Moreover, the $f l s 2$ mutants were able to rescue the virulence defects of COR-deficient Pst DC3118. fls2 exhibited more susceptibility to Pst DC3118 than the wild type since they failed to close stomata in response to the infection. When Pst DC3118 was infiltrated directly into the leaf apoplast, fls 2 and the wild-type plants showed similar susceptibility [44]. Thus, FLS2 plays a critical role in Pst DC3000-triggered stomatal closure. Flg22-induced and FLS2-mediated stomatal movement is mechanistically linked to SA and ABA signaling, including the guard cell-specific kinase OPEN STOMATA 1/SUCROSE NONFERMENTING 1-RELATED PROTEIN KINASE 2.6 (OST1/SnRK2.6) (Figure 1). In SAdeficient nah $G$ transgenic plants and SA-biosynthetic mutant enhanced disease susceptibility 16/salicylic acid induction deficient 2 (eds16/sid2), Pst DC3000 was not able to trigger stomatal closure. Similarly, flg22 could not induce stomatal closure in ABA signaling mutant ost12 or ABA-deficient mutant aba deficient 3 (aba3-1) [15]. Although exogenously applied ABA could induce stomatal closure responses in SA-deficient mutants, stomatal closure responses in ABA biosynthetic mutant aba2-1 were insensitive to exogenous SA. On the other hand, SA treatment could not induce stomatal closure in nonexpresser of pr genes 1-1 (npr1-1), an SA receptor mutant. Conversely, stomatal closure responses in npr1-1 and fls2 mutants were sensitive to exogenously applied ABA [44]. Taken together, SA acts upstream of ABA in flg22-FLS2-mediated stomatal closure. Flg22-triggered rapid stomatal closure was altered in fls2 and ost1. In contrast, aba insensitive 1-1 (abi1-1) was still sensitive to flg22-mediated rapid stomatal closure. Although both flg22 and ABA signaling activate the same anion channels through OST1 in regulating stomatal closure, it seems that the flg22-FLS2 and ABA signaling pathways diverge upstream of OST1 [45] (Figures 2 and 3).

Many receptor RLKs require a different RLK functioning as a co-receptor to transduce varied extracellular signals [24]. BAK1 was the first identified co-receptor RLK, which functions together with the major brassinosteroid (BR) receptor BRASSINOSTEROID INSENSITIVE 1 (BRI1) to mediate BR signaling in regulating plant growth and development $[46,47]$ The water loss rate of bak1 was higher than the wild type, and ABA could not induce stomatal closure in bak1, suggesting that BAK1 is required for ABA-triggered stomatal closure [48]. Biochemical assays revealed that BAK1 interacts with and phosphorylates the guard-cell-specific OST1 kinase to regulate ABA-induced stomatal closure. ABA could induce increased ROS levels in guard cells of the wild type, whereas ROS production in the bak1 mutant was insensitive to exogenous ABA. These results indicated that BAK1 functions upstream of ROS production in ABA-induced stomatal closure [48]. The binding of flg22 
to FLS2 induced the heteromerization and reciprocal phosphorylation between FLS2 and BAK1 during immune responses [27]. Moreover, BAK1 functions as a co-receptor of FLS2 in flg22-triggered immune response [27-29,49]. Taken together, these results suggest that FLS2 and BAK1 may form a receptor complex to regulate stomatal immunity (Figure 2).

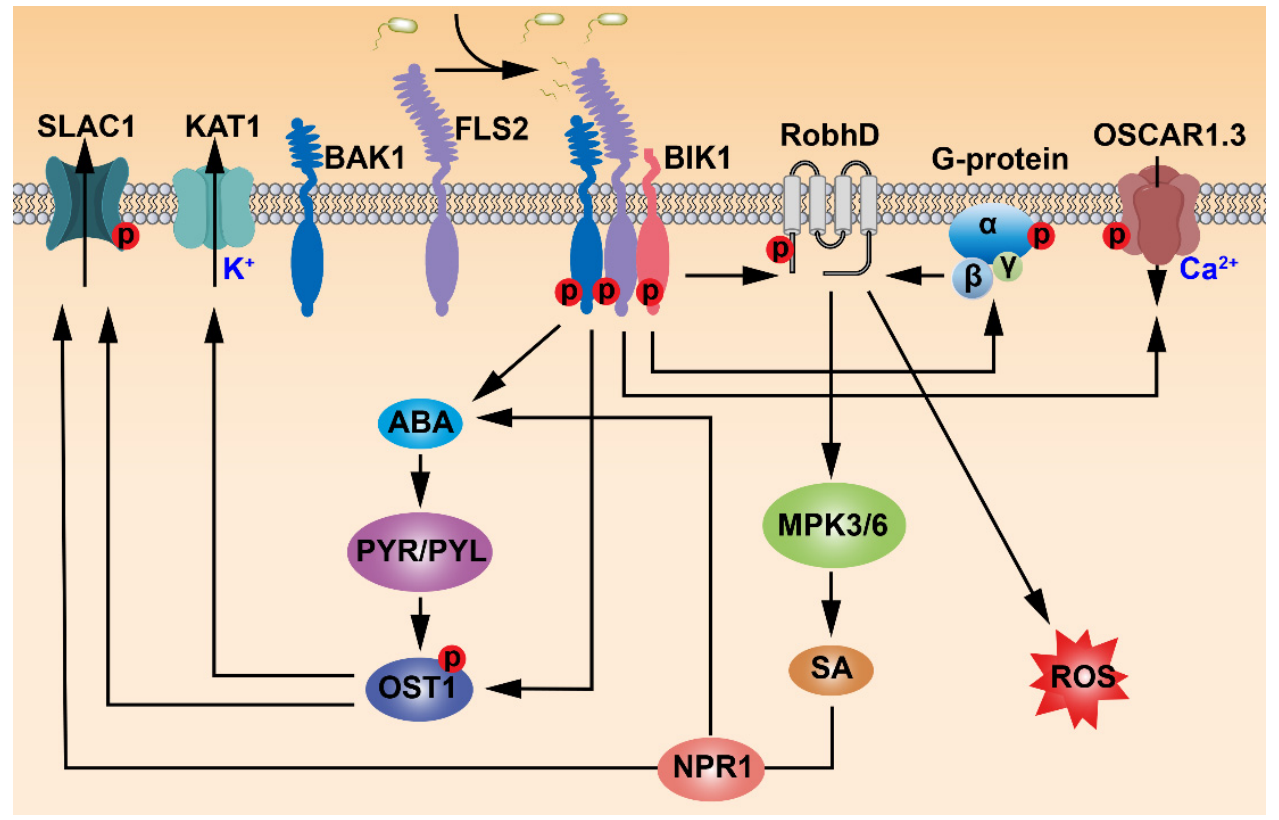

Figure 2. FLS2-mediated stomatal immunity. The FLS2 PRR complex plays a central role in Pst DC3000-triggered stomatal closure. FLS2 interacts with BAK1 and a receptor-like cytoplasmic kinase (RLCK) BOTRYTIS-INDUCED KINASE 1 (BIK1) to form a PRR complex in regulating stomatal immunity. BAK1 interacts with and phosphorylates OST1 to regulate ABA-induced stomatal closure by activating an S-type anion channel SLOW ANION CHANNEL-ASSOCIATED 1 (SLAC1) and a K ${ }^{+}$ channel in stomatal immunity. BIK1 interacts with and phosphorylates EXTRA-LARGE G PROTEINS (XLGs) to regulate RESPIRATORY BURST OXIDASE HOMOLOGUE D (RbohD)-mediated ROS production. BIK1 can also phosphorylate RbohD directly to control ROS production in stomatal immunity. The FLS2 PRR complex regulates stomatal closure through phosphorylating $\mathrm{Ca}^{2+}$-permeable channel OSCA1.3 by BIK1, increasing the channel activity of OSCA1.3. Salicylic acid (SA) accumulation is triggered by PRR and activates SLAC1 through NPR1-mediated signaling. The SA signaling can regulate ABA biosynthesis and positively modulate stomatal immunity.

Receptor-like cytoplasmic kinases (RLCKs) are a class of RLK that are anchored to the plasma membrane but lack the extracellular ligand-binding domain. RLCKs play essential roles in plant innate immunity, response to stresses, and development [50]. The Arabidopsis genome encodes a total of 149 RLCKs that were divided into 17 subfamilies based on their phylogeny [51]. The Arabidopsis RLCK VII subfamily consists of 46 members, and most of them are involved in PAMP-triggered immune signaling [52]. For example, BOTRYTISINDUCED KINASE 1 (BIK1) interacted with FLS2 to mediate PTI [53]. Flg22 treatment could induce calcium influx in the wild type, which depends on FLS2 [54,55]. However, the calcium influx level in bik1 was only about half of that in the wild type when bik1 was treated with flg22, which implied that BIK1 functions downstream of FLS2-mediated flg22 signaling [53]. ROS in plant guard cells plays a critical role during responses to pathogen attack or abiotic stress [10,56]. FLS2-mediated PTI is usually accompanied by a transient ROS burst, which depends on phosphorylation of RESPIRATORY BURST OXIDASE HOMOLOGUE D (RbohD), a nicotinamide adenine dinucleotide phosphate (NADPH) oxidase that is a key enzyme in generating ROS [53,57-59]. ROS production mediated by RbohD was necessary for flg22-FLS2-triggered stomatal movement during immunity to Pseudomonas syringae $[53,60]$. Biochemical results showed that RbohD directly interacted with BIK1 and 
FLS2, and BIK1 could phosphorylate RbohD at multiple sites. The phosphorylation of Ser39 and Ser343 in RbohD enhanced ROS production and was necessary for flg22-induced stomatal closure $[53,60]$. Calcium-dependent protein kinases (CPKs) were indicated to regulate ROS production during plant immunity [54,58,61]. Overexpression of CPK5 could enhance the phosphorylation of Ser39 in RbohD during PAMP-mediated stomatal immunity [62]. However, $\mathrm{LaCl}_{3}$, a calcium channel blocker, could not inhibit the phosphorylation of Ser39 in RbohD, suggesting that phosphorylation of RbohD by BIK1 is independent of CPK5 [53]. Altogether, these data indicated that FLS2, BAK1, and BIK1 function together to regulate stomatal immunity through RbohD-mediated ROS production (Figure 2).

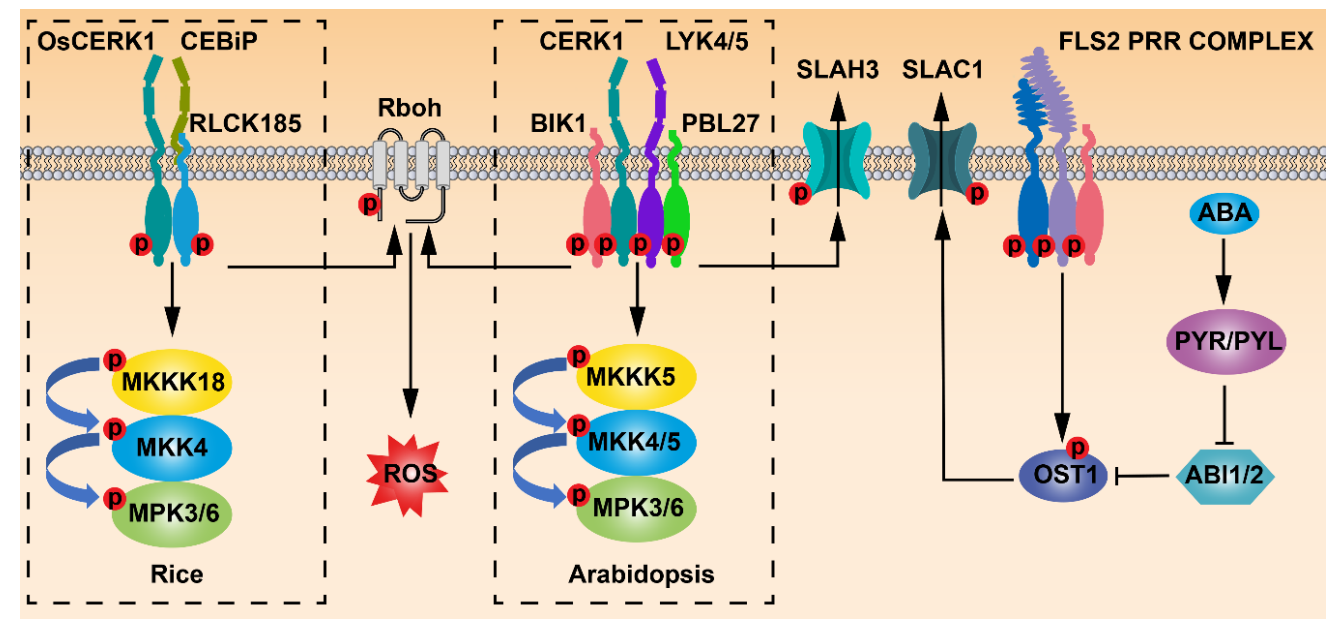

Figure 3. PRRs regulate stomatal immunity through different signaling pathways. Environmental factors regulate stomatal movement through ABA signaling pathway-mediated phosphorylation of OST1 and SLAC1. The flg22-FLS2 signaling phosphorylates OST1 to activate SLAC1 in stomatal immunity. The flg22 and ABA signaling pathways converge on OST1. CHITIN ELICITOR RECEPTOR KINASE 1 (CERK1) and its homologs LYSM DOMAIN RECEPTOR-LIKE KINASE 4/5 (LYK4/5) form a PRR complex to perceive the chitin signal to regulate stomatal immunity through the MKKK5MKK4/5-MPK3/6 cascade in Arabidopsis. In rice, OsCERK1 and CHITIN OLIGOSACCHARIDE ELICITOR-BINDING PROTEIN (OsCEBiP) perceive the chitin signal to activate the MKKK18-MKK4MPK3 / 6 cascade in stomatal immunity. In Arabidopsis, the RLCK PBS1-Like 27 (PBL27) can directly interact with and phosphorylate SLAC1 after it perceives the chitin-CERK1 signal to close stomata. BIK1 and OsRLCK185 directly phosphorylate Rboh to regulate ROS production during stomatal immunity in Arabidopsis and rice, respectively.

Heterotrimeric $G$ proteins play a central role in signal transduction pathways of animals, which respond to various extracellular stimuli perceived by $G$ protein-coupled receptors (GPCRs) [63]. Although no canonical GPCR has been identified in plants, similar heterotrimeric $G$ proteins containing three subunits exist in plants. G PROTEIN ALPHA SUBUNIT 1 (GPA1), the Arabidopsis G $\alpha$ was reported to be involved in ABA-mediated stomatal movement. The water loss rate of gpal mutants was significantly higher than that of the wild-type plants because ABA failed to induce stomatal closure in gpa1. GPA1 was necessary for the inhibition of $\mathrm{K}^{+}$influx into guard cells by ABA and sphingosine-1phosphate (S1P), and the activation of anion channels by $\mathrm{pH}$-independent $\mathrm{ABA}[64,65]$. The flg22-FLS2 signaling could promote stomatal closure via inhibiting the $\mathrm{K}^{+}$influx channels in guard cells. However, stomatal movement in gpa1 was insensitive to flg22 treatment [66], implying that the flg22-FLS2 signaling regulates stomatal immunity through a GPA1-dependent pathway. In addition, plants encode specific extra-large G proteins (XLGs) which exhibit significant homology to animal and plant G $\alpha$ subunits [67]. XLG2 directly interacted with the FLS2-BIK1 PRR complex in the pre-activation state, inhibiting the proteasome-mediated degradation of BIK1, together with the G $\beta$ subunit AGB1 and $\mathrm{G} \gamma$ subunits AGG1/2. When FLS2 perceived flg22, BIK1 phosphorylated the $\mathrm{N}$ terminus of 
XLG2 that then dissociated from the heterotrimeric $G$ protein complex. The phosphorylated XLG2 could activate RbohD to produce ROS that induced stomatal closure [68]. These data demonstrated that G proteins are essential for FLS2-mediated stomatal movement in response to biotic stresses (Figure 2).

In terrestrial plants, the stomatal aperture is controlled by turgor changes caused by the transmembrane channel-regulated ion flux. For instance, the current change resulted by the transmembrane $\mathrm{K}^{+}$flux regulates ABA- and flg22-induced stomatal closure [64,65]. Flg22 triggered membrane depolarization, which resulted in $\mathrm{K}^{+}$efflux of guard cells and thus stomatal closure. In the fls 2 mutant, flg22 treatment did not change the $\mathrm{K}^{+}$current of guard cells [66], suggesting that the flg22-FLS2 signaling regulates stomatal immunity through a $\mathrm{K}^{+}$channel-dependent pathway. SLOW ANION CHANNEL-ASSOCIATED 1 (SLAC1) is an anion channel required for regulating stomatal responses to environment and pathogen stimuli. The S-type anion channels can transmit $\mathrm{Cl}^{-}$and malate efflux in guard cells that cause stomatal closure by decreasing guard cell osmotic $[69,70] .\left[\mathrm{Ca}^{2+}\right]_{\text {cyt }}$ and ABA could not activate stomatal closure in the slac1 mutants, suggesting that SLAC1 mediates stomatal movement downstream of ABA and $\left[\mathrm{Ca}^{2+}\right]_{c y t}[71,72]$. SLAC1 also plays a role in PAMP-mediated stomatal immunity. A very low concentration of flg22 could activate SLAC1, whereas stomatal closure of the slac1 mutant was less sensitive to flg22 treatment [45]. Recently, a $\mathrm{Ca}^{2+}$-permeable channel OSCA1.3 was identified in Arabidopsis, which was involved in FLS2-mediated stomatal immunity. OSCA1.3 could be activated rapidly with the treatment of flg22. BIK1 could interact with and phosphorylate the Nterminal of OSCA1.3, which activated the N-terminal and increased the channel activity of OSCA1.3 [73]. Taken together, the current knowledge supports that FLS2-mediated flg22 signaling requires transmembrane ion flux to regulate stomatal immunity (Figure 2).

\section{CERK1-Mediated Chitin Signaling Regulates Stomatal Immunity}

RLKs with lysin-motif (LysM) ectodomains were supposed to recognize specific molecules with $N$-acetylglucosamine, such as chitin, peptidoglycan (PGN), and rhizobial nodulation factor (NF). Chitin is a $\beta-1,4$-linked homopolymer of $N$-acetylglucosamine, which mainly exists in the cell walls of most of the higher fungi [38]. Chitin is conferred as a PAMP that elicits plant immunity. Similar to flg22, treatment with chitin elicitor leads to stomatal closure [74], suggesting that stomatal immunity can be triggered by chitin. Mutation in CHITIN OLIGOSACCHARIDE ELICITOR-BINDING PROTEIN (OsCEBiP), the first plant chitin receptor identified in rice (Oryza sativa), resulted in the suppression of the elicitor-induced oxidative burst as well as the downstream gene responses [75]. OsCE$\mathrm{BiP}$ is a LysM-type receptor-like protein (LysM-RLP), which lacks a cytoplasmic kinase domain, implying that it must cooperate with another protein kinase to initiate chitin signaling. OsCERK1 was later identified to form a hetero-oligomeric receptor complex with OsCEBiP for perceiving chitin [76]. CERK1/LYK1 and LYK4/5 are the orthologs of OsCERK1 in Arabidopsis. CERK1 functions as chitin receptor to mediate chitin-triggered immunity $[77,78]$. The lyk4 lyk5-2 double mutants exhibited complete insensitivity to chitin treatment, suggesting that LYK4/5 may form a complex with CERK1 to recognize chitin. In fact, chitin could induce LYK5 to interact with CERK1, and LYK5 binding to chitin was necessary for CERK1 phosphorylation [31]. Although chitoheptaose or chitin treatment could not induce the interaction between CERK1 and LYK4, the ectodomains of LYK4 and LYK5 showed physical interaction and LYK4 could form homodimers in vitro. Therefore, LYK4 may function as a co-receptor or scaffold protein of CERK1 to form the receptor complex of chitin in Arabidopsis [79,80].

RLCK and MAPK cascade play critical roles in chitin-triggered immunity. Silencing the expression of OsRLCK185 interfered with chitin-mediated immunity responses, such as MAPK activation and downstream gene expression. OsRLCK185 interacted with and was phosphorylated by OsCERK1 [81]. OsRLCK185 was required for chitin-induced phosphorylation of OsMPK3 and OsMPK6 [81], suggesting that OsRLCK185 bridges the CERK1-CEBiP complex and MAPK cascade in chitin-triggered rice immunity. Moreover, 
chitin treatment enhanced the phosphorylation level of OsMPK6 by OsMKK4, and the kinase activities of OsMPK3 and OsMPK6 were activated by induced expression of constitutively activated OsMKK4 [82]. OsMKKK11 and OsMKKK18 were identified to interact with OsRLCK185 in vitro. Transient expression of OsMKKK11 or OsMKKK18 in Nicotiana benthamiana led to immune responses such as cell death. In addition, OsMKKK18 could be phosphorylated by OsRLCK185, and interaction between OsMKKK18 and OsMKK4 was detected with a yeast two-hybrid assay [83]. These data indicated that the OsMKKK18OsMKK4-OsMPK3/6 signaling cascade transduces the chitin elicitor signal perceived by CERK1-CEBiP-OsRLCK185 to mediate rice immune responses.

A counterpart of chitin-triggered signaling cascade downstream of the receptor complex was also identified in Arabidopsis. PBS1-Like 27 (PBL27), an Arabidopsis ortholog of OsRLCK185, interacts with CERK1 at the plasma membrane. The pbl27 mutants were less sensitive to chitin treatment, and the chitin-triggered activation of MPK3/6 was not observed in pbl27, which supported that a MAPK cascade containing MPK3/6 functions downstream of PBL27 to regulate chitin-mediated immunity in Arabidopsis [84]. An Arabidopsis MEKK subfamily member MKKK5 was identified to interact with PBL27 both in vivo and in vitro. The in vitro kinase assay revealed that PBL27 phosphorylated the C-terminal domain of MKKK5. MKKK5 could interact with and phosphorylate MKK4 and MKK5. Consistently, the absence of MKKK5 significantly reduced MPK3/6 activation triggered by a chitin elicitor [85]. It was reported that the inducible double mutants of $m p k 3 / 6$ and $m k k 4 / 5$ were more susceptible to pathogens than the wild type because the stomata of the mutants failed to be closed during pathogen invasion [86], which suggested that MKK4/5 and MPK3/6 are required for PAMP-induced stomatal immunity. Taken together, these data implied that chitin may regulate stomatal immunity through the CERK1-PBL27-MKKK5-MKK4/5-MPK3/6 phospho-signaling pathway (Figure 3).

Recently, a study revealed that PBL27 directly binds with the anion channel SLAC1 homolog 3 (SLAH3) to regulate chitin-induced stomatal immunity [87]. SLAH3 interacted with PBL27 in vitro, and PBL27 could phosphorylate SLAH3 at S127 and S189. The mutants with S127A and S189A exhibited defective stomatal closure, which was insensitive to chitin treatment. Enhanced phosphorylation of SLAH3 by PBL27 was observed after the plants were treated with chitin, suggesting that the activation of SLAH3 by PBL27 depends on chitin stimulation. Consistently, S-type anion currents could be detected only when SLAH3 was co-injected with PBL27. The activation of SLAH3 by PBL27 was not suppressed by ABI1, whereas ABI1 inhibited CBL1/CIPK23-mediated phosphorylation of SLAH3. Therefore, PBL27-regulated SLAH3 activity was possibly independent of ABA signaling [87]. It was reported that flg22-FLS2 signaling can activate OST1 which then phosphorylates S-type anion channel SLAC1 to regulate stomatal immunity [45]. However, there is no evidence to show that BIK1, the RLCK downstream of the FLS2 signaling pathway, directly interacts with an anion channel to regulate stomatal immunity (Figure 3).

One of the main functions of apoplastic ROS produced by Rbohs is to regulate stomatal movement [88]. Chitin-elicited plant immune responses also include ROS production [74]. As mentioned above, PBL27 activates a MAPK cascade, but not ROS production in chitinmediated immunity [84]. However, a study revealed that chitin-triggered ROS production also depends on the phosphorylation of RbohD by BIK1, similar to that of flg22-triggered ROS production in FLS2-mediated immune signaling [53,60]. Intriguingly, OsRLCK185 was involved in both chitin-triggered MAPK activation and ROS production in rice [81]. Although the mechanism by which OsRLCK185 regulates ROS production is still unknown, it is still reasonable to propose that OsRLCK185 may regulate the phosphorylation of Rboh to produce ROS in a way similar to BIK1. It is worth pointing out that OsRLCK185 is required in rice for both ROS production and MAPK signaling triggered by chitin, two immune responses in Arabidopsis mediated by BIK1 and PBL27, respectively, which suggests that the functions of these RLCK VII members are differentiated in chitin-induced stomatal closure. 


\section{LecRKs Mediate Various Signals to Regulate Stomatal Immunity}

Lectin receptor kinases are a group of RLKs which contain an extracellular lectin motif predicted to bind various carbohydrates such as oligosaccharides [89]. Plant lectin receptor kinases were classified into three subgroups according to their extracellular lectin motifs: G-type, C-type, and L-type [90]. Because the extracellular domain is similar to soluble legume lectins that are universal in leguminous seeds, L-type lectin receptor kinases (LecRKs) are also known as legume-like lectin receptor kinases [90]. Accordingly, LecRKs are supposed to perceive oligosaccharides released from pectin [89]. A total of 45 LecRKs are encoded by the Arabidopsis genome, which were divided into 9 sub-groups (I to IX) and 7 singletons (LecRK S.1 to S.7) [90]. In the past decade, the functions of some LecRKs have been discovered. Many LecRK genes are rarely transcribed during plant development, but their expression levels could be induced by elicitors or pathogens [90], implying that LecRKs may be critical for plant immunity or stress responses.

ATP is generally considered the universal energy currency in organisms. However, ATP released into the extracellular matrix (eATP) functions as a signal molecule to mediate various stress responses and immune responses [91,92]. eATP plays a role in stomatal opening by triggering ROS production in guard cells of the wild type [93]. In contrast, the ATP-induced ROS increase was not observed in atrbohD/F. Moreover, the ATP-triggered $\mathrm{Ca}^{2+}$ influx and $\mathrm{H}^{+}$efflux in guard cells were significantly suppressed in atrbohD/F. Similarly, the $\mathrm{Ca}^{2+}$ influx and $\mathrm{H}^{+}$efflux induced by ATP treatment were not detected in gpa1 mutants [93]. These data demonstrated that eATP functions upstream of ROS production and G-protein to regulate stomatal movement. Similar mechanisms were found in other species. For instance, eATP stimulates stomatal opening in Vicia faba by activating $\mathrm{Ca}^{2+}$ channels in guard cells [94]. DOES NOT RESPOND TO NUCLEOTIDES 1 (DORN1/LecRK I.9) was the first eATP receptor identified in plants through a forward genetic screen for mutants insensitive to ATP [37]. A recent study indicated that DORN1/LecRK I.9 directly phosphorylated RbohD to mediate the production of ROS in guard cells and induce stomatal closure [95]. Interestingly, the conclusion that eATP signal promotes stomatal closure in this study [95] seems opposite to the previous results $[93,94]$. It should be noted that the concentrations of ATP used in the physiological experiments were significantly different in these independent studies, implying that the concentration of eATP may be a critical factor in regulating stomatal movement, or that eATP regulates stomata aperture in immunity through various signaling pathways. Microarray analysis revealed that a number of eATP-induced genes that play roles in plant defense responses were also involved in the JA signaling pathway. eATP induced the degradation of JASMONATE ZIM-DOMAIN PROTEIN 1 (JAZ1), a repressor of JA signaling, through the $\mathrm{SCF}^{\mathrm{COI1}}$-proteasome pathway [96]. Consistent with the previous studies $[93,97]$, the second messengers, such as $\mathrm{Ca}^{2+}$, ROS, and NO, were necessary for eATP-activated JA signaling [96]. Based on these results, the eATP-DORN1/LecRK I.9 signaling pathway may mediate plant immunity and stomatal movement by employing JA signaling components.

Nicotinamide adenine dinucleotide $\left(\mathrm{NAD}^{+}\right)$was considered the precursor of the second messenger cyclic ADP-ribose (cADPR) that triggers $\mathrm{Ca}^{2+}$ signaling in organisms [98-100]. Despite the fact that $\mathrm{NAD}^{+}$functions as a signal molecule, the potential receptor of $\mathrm{NAD}^{+}$ in plants was not found until Arabidopsis LecRK-I.8, a homolog of DORN1/LecRK-I.9, was identified to sense extracellular $\mathrm{NAD}^{+}\left(\mathrm{eNAD}^{+}\right)$[101]. Exogenous $\mathrm{NAD}^{+}$application induced $P R$ gene expression in the wild type but failed in the lecrk-I.8 mutants [101,102]. The lecrk-I.8 mutants exhibited significantly elevated susceptibility to a low concentration of bacterial pathogen P. syringae pv. maculicola (Psm ES4326) [101]. Furthermore, LecRK-I.8 specifically bound with NAD ${ }^{+}$. Therefore, LecRK-I.8 functions as a potential receptor of eNAD ${ }^{+}$to play a positive role in plant immunity. LecRK-VI.2 is the second potential receptor of eNAD ${ }^{+}$as well as extracellular $\mathrm{NAD}^{+}$phosphate $\left(\mathrm{eNADP}^{+}\right)$, which plays a key role in the biological induction of systemic acquired resistance (SAR). LecRK-VI.2 interacted with BAK1 both in vivo and in vitro [103], and associated with FLS2 upon flg22 elicitation [36], implying that LecRK-VI.2 may be required for plant PTI. Several PTI 
responses including stomatal closure triggered by flg22 were impaired in the lecrk-VI.2-1 mutants [104]. Based on these results, a NADP ${ }^{+}$signal is necessary for flg22-FLS2/BAK1mediated stomatal immunity although the detailed mechanisms need to be further explored in the future (Figure 4).

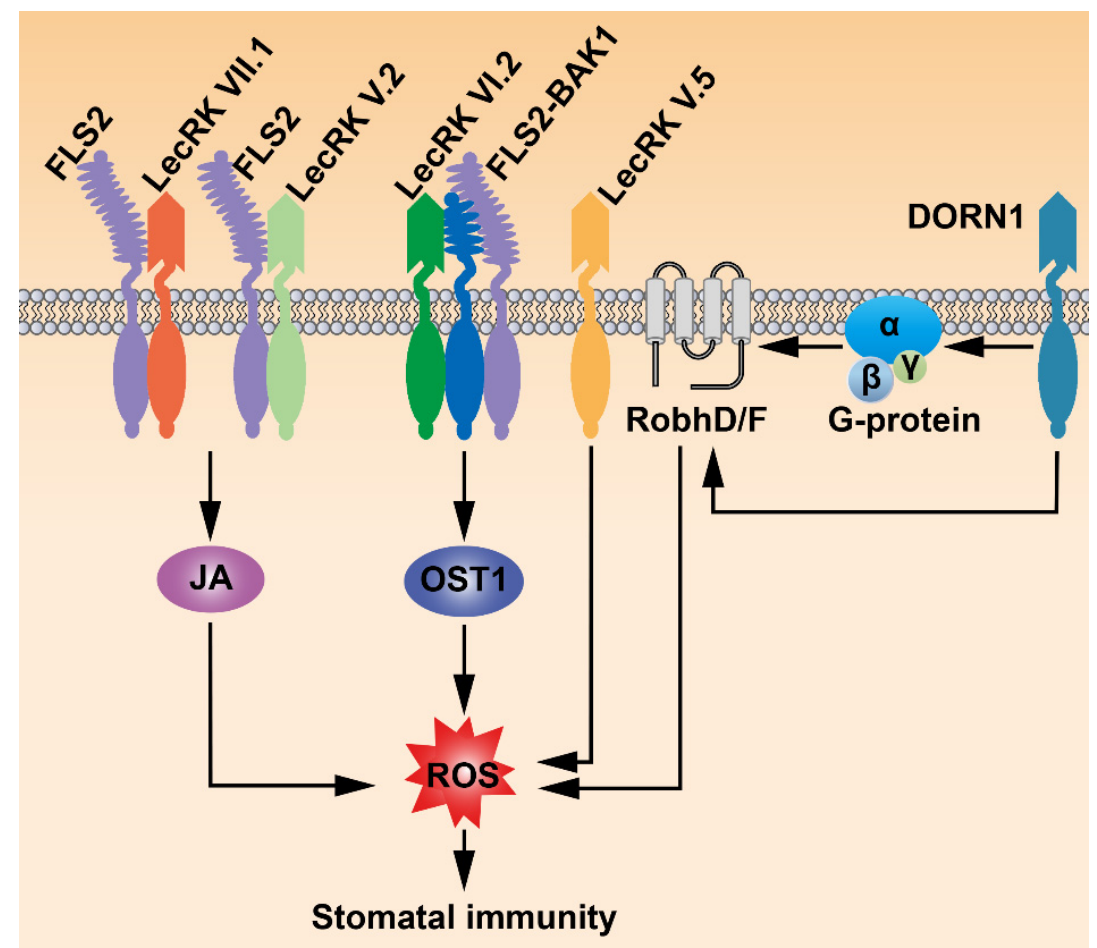

Figure 4. LecRKs regulate stomatal immunity. DOES NOT RESPOND TO NUCLEOTIDES 1 (DORN1/LecRK I.9) perceives extracellular ATP (eATP) to mediate the production of ROS in stomatal closure through G protein-dependent or -independent pathways. LecRK-VI.2 associates with the FLS2 PRR complex to regulate PAMP-induced stomatal immunity. LecRK-V.5 regulates stomatal immunity upstream of ABA-mediated ROS burst. LecRK-V.2 and LecRK-VII.1 function in a nonredundant way to regulate stomatal movement in immunity through the JA signal pathway.

Loss of LecRK-V.5 function increased plant resistance to Pst DC3000. Fewer bacteria and disease symptoms were observed in the lecrk-V.5 mutants than the wild type because the stomata were closed in the mutants during the bacterial invasion, suggesting that LecRKV.5 negatively regulates stomatal immunity [105]. Consistently, LecRK-V.5 is expressed in stomatal guard cells. Pst DC3000 treatment failed to re-open the stomata of the lecrk-v.5 mutants while transgenic lines overexpressing LecRK-V.5 did not show PAMP-triggered stomatal closure [105]. Moreover, significantly elevated levels of ROS in guard cells were detected in the lecrk-v.5 mutants, whereas overexpression of LecRK-V.5 resulted in reduced ROS production after ABA treatment [105]. Collectively, LecRK-V.5 negatively regulates stomatal immunity and functions upstream of ABA-mediated ROS burst (Figure 4). Two other LecRKs, LecRK-V.2 and LecRK-VII.1, are also expressed in stomatal guard cells. The lecrk-v.2 and lecrk-vii.1 mutants showed more susceptibility to Pst DC3000 because stomatal closure of these mutants was defective when inoculated with Pst DC3000. On the other hand, the lecrk-v.2/vii.1 double mutants showed similarly increased susceptibility when compared with both single mutants [106]. Taken together, LecRK-V.2 and LecRK-VII.1 control stomatal immunity independent of each other. Both LecRK-V.2 and LecRK-VII.1 were part of the FLS2 PRR complex, and the interactions between LecRK-V.2/VII.1 and FLS2 could be induced by flg22 [106]. Although the guard cells of both lecrk-v.2 and lecrkvii.1 mutants exhibited similar responses to ABA as the wild type, MeJA failed to induce stomatal closure in these mutants. In addition, ROS production in guard cells triggered by 
flg22 was not observed in the lecrk-V.2 and lecrk-VII.1 mutants. These results indicated that LecRK-V.2 and LecRK-VII.1 may function together with FLS2 to control stomatal immunity in a nonredundant manner through the JA signaling pathway (Figure 4).

Arabidopsis LecRKs are involved in a variety of biological processes, including development and responses to stimuli. For example, LecRK-IV.2 was identified to regulate pollen development [107]. LecRK-VIII.2 functions upstream of a MAPK cascade to control seed size and number [108]. More and more LecRKs were found to play crucial roles in plant immunity $[36,105,106,108,109]$. Interestingly, although these LecRKs share similar extracellular lectin motifs, they regulate immune responses in distinct pathways, suggesting that the functions of these LecRK members differentiated during the process of evolution. For example, LecRK-V.5 negatively regulates stomatal closure in immune response [105], whereas LecRK-V.2 plays a positive role in FLS2-mediated stomatal immunity [106]. Intriguingly, their homologous LecRK-V.7 is involved in LPS-mediated immunity [110]. On the other hand, the functional diversification of LecRKs is also embodied in various signal molecules that they sense in response to pathogen invasion. For instance, DORN1/LecRKI.9 perceives the eATP signal; LecRK-I.8 senses eNAD ${ }^{+}$; LecRK-VI.2 is involved in the perception of eNAD ${ }^{+}$and $\mathrm{eNADP}^{+}[37,101,103]$. It is worth noting that both LecRK-I.8 and LecRK-VI.2 can sense the eNAD ${ }^{+}$signal. How the specificity of these two LecRK-mediated $\mathrm{eNAD}^{+}$signaling is determined needs to be investigated in the future. It appears that the major roles of LecRKs that have been studied are to regulate plant immunity. What possible immune responses are regulated by the remaining LecRKs, are worth further exploration.

\section{Malectin-Like Receptor Kinases Function with FLS2 to Mediate Stomatal Immunity}

Plant malectin-like receptor kinases possess a characteristic extracellular malectin-like domain that is proposed to recognize oligosacharrides, glycosylated proteins, and cell wall degradation products [111,112]. These RLKs are also known as Catharanthus roseus receptor-like kinase 1-like proteins (CrRLK1Ls). They are involved in many biological processes including development, sexual reproduction, plant immunity, and stress response [30,113-116]. FER was reported to control male-female interactions during pollen tube reception in Arabidopsis [114]. FER also plays an important role in plant immunity. The enhanced accumulation of ROS, flg22-triggered MAPK activation and callose deposition were observed in the fer mutants, and the fer stomata were constitutively closed, which led to less bacterial proliferation than the wild-type plants [117]. Thus, FER may associate with FLS2 to regulate various plant immune processes, including stomatal immunity.

RAPID ALKALINIZATION FACTOR 1 (RALF1) was identified to function as a peptide hormone perceived by FER to regulate plant cell expansion [118], suggesting that FER may function as a receptor to sense other RALFs in regulating plant immunity. A forward genetic screen identified RALF23 that functions as a negative regulator in plant immunity [119]. RALF23 treatment or overexpression inhibited PAMP-triggered ROS production in plants and increased their susceptibility to Pst DC3000 cor- ${ }^{-}$However, RALF23 failed to inhibit elf18-induced ROS production in the fer mutants, indicating that RALF23 is specifically involved in FLS2-mediated plant immunity. The binding of RALF23 disturbed FER-mediated complex formation between FLS2 and its co-receptor BAK1, which suggested that FER acts as a RALF-regulated scaffold for PRR complexes and thus positively regulates immunity [119]. The phytotoxin COR can hijack the host JA signaling pathway as a structural mimic of JA-Ile to re-open stomata for the invasion of more bacteria into the host plant [17]. A great number of genes with overlapping expression upregulated in both fer and COR/JA-induced seedlings were identified, suggesting that FER negatively regulates COR/JA signaling. FER interacted with and phosphorylated MYC2, resulting in the destabilization of MYC2. Furthermore, the phosphorylation of MYC2 was RALF23dependent [30]. In summary, the RALF23-FER-MYC2 signaling pathway is necessary for COR-mediated host disease susceptibility. 


\section{Conclusions and Future Perspectives}

For many pathogens, entry into the apoplastic space is the first critical step to infect the host plant. Stomata are the main entrance for many pathogens to enter into the host tissues. Therefore, immunity occurring in guard cells is the first line of defense against bacteria or fungi. Although the importance of stomata in immune processes has long been recognized [120,121], the mechanism was not revealed until it was found that stomatal closure induced by bacteria requires FLS2 and the guard cell-specific OST1 kinase [15]. This discovery indicated that stomatal movement during bacterial invasion is an important part of plant innate immunity. Plant RLK signaling pathways function in a variety of biological processes, including the defense responses to microbial signals [38,122,123]. Many RLKs, such as PRRs (FLS2, CERK1, EFR), LecRKs, and CrRLK1Ls, were reported to regulate stomatal immunity. As discussed above, the mechanisms of these RLKs regulating stomatal movement in immunity have been investigated in detail.

Recently, several studies deciphered some other RLK-mediated signal pathways involved in the regulation of stomatal movement. GUARD CELL HYDROGEN PEROXIDERESISTANT 1 (GHR1) is a member of the Arabidopsis LRR-RLK subfamily. The stomata of ghr1 mutants showed impaired responses to elevated $\mathrm{CO}_{2}, \mathrm{ABA}$, light-dark transitions, and flg22. GHR1 activated SLAC1 via forming a complex with CALCIUM-DEPENDENT PROTEIN KINASE 3 (CDPK3) and SLAC1 [124,125]. Although current data showed that GHR1 is necessary for flg22-triggered stomatal immunity [125], whether GHR1 functions downstream of FLS2 remains to be clarified. Arabidopsis KINASE 7 (KIN7) was assumed to be a receptor of LPS [126], that phosphorylates TANDEM PORE K ${ }^{+}$CHANNEL 1 (TPK1) to regulate $\mathrm{ABA}$ - and $\mathrm{CO}_{2}$-mediated stomatal closure [127]. RECEPTOR-LIKE PROTEIN KINASE 1 (RPK1) was supposed to be a positive regulator in ABA signaling. Lack of RPK1 impaired ABA-induced stomatal closure, while overexpression of OST1 completely rescued the defects of $r p k 1$ in response to ABA [128]. Arabidopsis STRESS INDUCED FACTOR 2 (SIF2) directly interacted with the FLS2-BAK1 PRR complex and SLAC1 and phosphorylated SLAC1 to mediate ABA-mediated stomatal immunity [129]. Although the detailed mechanisms mediated by these RLKs still need to be investigated, it looks like many of them function in stomatal immunity through regulating the activities of various ion channels directly or indirectly. The fact that so many RLKs were identified to regulate stomatal immunity also reminds us that plants are facing numerous environmental stimuli and there must be more RLKs involved in stomatal immunity. These RLKs responding to different environmental stimuli need to be identified, and their detailed mechanisms regulating stomatal immunity should be investigated in the future.

It has been revealed that various extracellular signals contribute to stomatal immunity. These signals include PAMPs, extracellular purines, and peptide hormones, which are usually sensed by RLKs. For instance, FLS2 and DORN1/LecRK-I.9 directly perceive the flg22 and eATP signals, respectively, to regulate stomatal immunity [15,37,42,43,95]. Possibly, distinct RLK receptors are employed to sense various PAMPs from different pathogens. At the same time, pathogen invasions lead to damages of plant cells, generating various infection-related molecules such as peptides and oligosaccharides that need to be sensed by a variety of RLK receptors to coordinately control stomatal responses. Multiple RLK-mediated signaling pathways make it reliably effective to guard pathogen invasion during stomatal immunity. It should be pointed out that the ligands of many RLKs in stomatal immunity, such as GHR1, LecRK-V.2, LecRK-VII.1, have not been identified yet. Some studies reported that several other RLKs regulating stomatal movement were associated with the FLS2 PRR complex, such as LecRK-V.2, LecRK-VII.1, FER, and SIF2 [106,119,129], which suggested that FLS2 may play a central role in stomatal immunity by integrating these signaling pathways. On the other hand, these RLKs and FLS2 may form a specific receptor complex to mediate the flg22 signal, which is at least partially supported by the results that flg22-triggered immune responses in guard cells were not detected in lecrk-V.2 and lecrk-VII.1 [106]. 
Usually, the FLS2-mediated signaling regulates stomatal immunity by ultimately modulating the activities of transporters or channel proteins localized in the plasma membrane through multi-pathways downstream of FLS2 to control stomatal aperture during the immune response $[45,53,66,73]$. One of these pathways is the MAPK signaling cascade. MAPK cascades were reported as key components downstream of FLS2 to regulate plant immunity. The MEKK1-MKK4/5-MPK3/6 cascade is downstream of FLS2 to modulate Arabidopsis resistance to pathogens [130]. The MEKK1-MKK1/2-MPK4 cascade downstream of FLS2 contributes to plant PTI [131,132]. Similarly, MAPK signaling also plays a critical role downstream of FLS2 in stomatal immunity. For instance, decreased expression of $M P K 3$ resulted in stomatal movement insensitive to $\mathrm{ABA}$ and $\mathrm{H}_{2} \mathrm{O}_{2}$ [133]. Recent studies demonstrated that MKK4/5 and MPK3/6 transduce the flg22 signal and play crucial roles to control stomatal immunity by regulating the metabolism of osmolytes [86] and modulating actin remodeling via phosphorylation of VILLIN3 (VLN3) [134]. Some lines of evidence indicated that RLKs can phosphorylate transporters or channels directly or activate these membrane-localized protein machineries by RLCKs which are associated with RLKs. For example, CANALIZATION-RELATED, AUXIN-REGULATED MALECTIN-TYPE RLK (CAMEL), and CANALIZATION-RELATED RECEPTOR-LIKE KINASE (CANAR) directly activate PINFORMED (PIN) proteins that are auxin transporters to coordinately mediate auxin polarization [135]. Cyclic nucleotide-gated channel proteins CYCLIC NUCLEOTIDE GATED CHANNEL 2 (CNGC2) and CNGC4 are phosphorylated by BIK1 to increase the $\left[\mathrm{Ca}^{2+}\right]_{\text {cyt }}$ during pathogen invasion [136]. This non-genomic function paradigm also exists in RLK-mediated stomatal immunity possibly because stomatal movement triggered by pathogen invasion is a rapid response. For instance, FLS2 phosphorylates channel proteins directly or through RLCK and downstream kinases such as OST1 [48,73] (Figure 2). Therefore, other RLKs without known mechanisms, especially those LecRKs involved in stomatal movement, may regulate stomatal immunity through phosphorylating the targeting channel proteins or ion transporters after they perceive the signals during pathogen invasion. However, the downstream signaling components of these RLKs, such as co-receptors, RLCKs, MAPK cascades, and the possible targeting ion channels or transporters need to be identified.

Environmental factors, such as humidity, light, and temperature, also affect stomatal movement, and they often share similar downstream signaling events with PRR-triggered stomatal immunity, including phytohormone signaling, ROS production, and activation of channel proteins [71,72,137]. Environmental factors inducing stomatal opening may facilitate the invasion of pathogens. For example, air relative humidity (RH) is a major environmental factor affecting stomatal aperture. High RH may act as a suppressor of stomatal immunity, together with anti-stomatal defense factors such as coronatine, to benefit bacterial infection [138]. Whether RLKs involved in stomatal immunity play roles in regulating environmental factor-induced stomatal movement is an intriguing question. GHR1 functions in flg22-triggered stomatal closure [124,125], which is also necessary for stomatal closure caused by low-air-humidity-induced leaf-to-air vapor pressure difference [139], suggesting that environmental stimulus-induced stomatal movement and stomatal immunity may be regulated by the same RLK. The detailed mechanisms of how RLKs function to cope with the abiotic factor-suppressed stomatal immunity, however, need to be explored in the future.

Author Contributions: Z.W. and X.G. wrote the manuscript. All authors have read and agreed to the published version of the manuscript.

Funding: This work was supported by the National Natural Science Foundation of China (32170332, 31970339, 31770312), Fundamental Research Funds for the Central Universities (lzujbky-2021-kb05, lzujbky-2022-kb05), the 111 Project (B16022), and Lanzhou City's Scientific Research Funding Subsidy to Lanzhou University.

Conflicts of Interest: The authors declare no conflict of interest. 


\section{References}

1. Bergmann, D.C.; Sack, F.D. Stomatal development. Annu. Rev. Plant Biol. 2007, 58, 163-181. [CrossRef]

2. Lawson, T.; Matthews, J. Guard cell metabolism and stomatal function. Annu. Rev. Plant Biol. 2020, 71, 273-302. [CrossRef] [PubMed]

3. Lawson, T.; Oxborough, K.; Morison, J.I.; Baker, N.R. Responses of photosynthetic electron transport in stomatal guard cells and mesophyll cells in intact leaves to light, $\mathrm{CO}_{2}$, and humidity. Plant Physiol. 2002, 128, 52-62. [CrossRef] [PubMed]

4. Yao, Y.; Liu, X.; Li, Z.; Ma, X.; Rennenberg, H.; Wang, X.; Li, H. Drought-induced $\mathrm{H}_{2} \mathrm{O}_{2}$ accumulation in subsidiary cells is involved in regulatory signaling of stomatal closure in maize leaves. Planta 2013, 238, 217-227. [CrossRef]

5. Hsu, P.K.; Takahashi, Y.; Munemasa, S.; Merilo, E.; Laanemets, K.; Waadt, R.; Pater, D.; Kollist, H.; Schroeder, J.I. Abscisic acid-independent stomatal $\mathrm{CO}_{2}$ signal transduction pathway and convergence of $\mathrm{CO}_{2}$ and ABA signaling downstream of OST1 kinase. Proc. Natl. Acad. Sci. USA 2018, 115, E9971-E9980. [CrossRef] [PubMed]

6. Azoulay-Shemer, T.; Bagheri, A.; Wang, C.; Palomares, A.; Stephan, A.B.; Kunz, H.H.; Schroeder, J.I. Starch biosynthesis in guard cells but not in mesophyll cells is involved in $\mathrm{CO}_{2}$-induced stomatal closing. Plant Physiol. 2016, 171, 788-798. [CrossRef]

7. Schroeder, J.I.; Allen, G.J.; Hugouvieux, V.; Kwak, J.M.; Waner, D. Guard cell signal transduction. Annu. Rev. Plant Physiol. Plant Molec. Biol. 2001, 52, 627-658. [CrossRef] [PubMed]

8. Finkelstein, R.R.; Gampala, S.S.; Rock, C.D. Abscisic acid signaling in seeds and seedlings. Plant Cell 2002, 14 (Suppl. S1), S15-S45. [CrossRef]

9. Manthe, B.; Schulz, M.; Schnabl, H. Effects of salicylic acid on growth and stomatal movements of Vicia faba L.: Evidence for salicylic acid metabolization. J. Chem. Ecol. 1992, 18, 1525-1539. [CrossRef]

10. Mori, I.C.; Pinontoan, R.; Kawano, T.; Muto, S. Involvement of superoxide generation in salicylic acid-induced stomatal closure in Vicia faba. Plant Cell Physiol. 2001, 42, 1383-1388. [CrossRef] [PubMed]

11. Munemasa, S.; Hossain, M.A.; Nakamura, Y.; Mori, I.C.; Murata, Y. The Arabidopsis calcium-dependent protein kinase, CPK6, functions as a positive regulator of methyl jasmonate signaling in guard cells. Plant Physiol. 2011, 155, 553-561. [CrossRef]

12. Munemasa, S.; Oda, K.; Watanabe-Sugimoto, M.; Nakamura, Y.; Shimoishi, Y.; Murata, Y. The coronatine-insensitive 1 mutation reveals the hormonal signaling interaction between abscisic acid and methyl jasmonate in Arabidopsis guard cells. Specific impairment of ion channel activation and second messenger production. Plant Physiol. 2007, 143, 1398-1407. [CrossRef] [PubMed]

13. Romantschuk, M.; Bamford, D.H. The causal agent of halo blight in bean, Pseudomonas syringae pv. phaseolicola, attaches to stomata via its pili. Microb. Pathog. 1986, 1, 139-148. [CrossRef] [PubMed]

14. Hirano, S.S.; Upper, C.D. Bacteria in the leaf ecosystem with emphasis on Pseudomonas syringae-a pathogen, ice nucleus, and epiphyte. Microbiol. Mol. Biol. Rev. 2000, 64, 624-653. [CrossRef] [PubMed]

15. Melotto, M.; Underwood, W.; Koczan, J.; Nomura, K.; He, S.Y. Plant stomata function in innate immunity against bacterial invasion. Cell 2006, 126, 969-980. [CrossRef]

16. Bender, C.L.; Stone, H.E.; Sims, J.J.; Cooksey, D.A. Reduced pathogen fitness of Pseudomonas syringae pv. tomato Tn5 mutants defective in coronatine production. Physiol. Mol. Plant Pathol. 1987, 30, 273-283. [CrossRef]

17. Staswick, P.E.; Tiryaki, I. The oxylipin signal jasmonic acid is activated by an enzyme that conjugates it to isoleucine in Arabidopsis. Plant Cell 2004, 16, 2117-2127. [CrossRef]

18. Ueda, M.; Egoshi, S.; Dodo, K.; Ishimaru, Y.; Yamakoshi, H.; Nakano, T.; Takaoka, Y.; Tsukiji, S.; Sodeoka, M. Noncanonical function of a small-molecular virulence factor coronatine against plant immunity: An in vivo raman imaging approach. ACS Cent Sci. 2017, 3, 462-472. [CrossRef]

19. Medzhitov, R.; Janeway, C., Jr. Innate immune recognition: Mechanisms and pathways. Immunol. Rev. 2000, 173, 89-97. [CrossRef]

20. Montillet, J.L.; Hirt, H. New checkpoints in stomatal defense. Trends Plant Sci. 2013, 18, 295-297. [CrossRef] [PubMed]

21. Yu, X.; Feng, B.; He, P.; Shan, L. From chaos to harmony: Responses and signaling upon microbial pattern recognition. Annu. Rev. Phytopathol. 2017, 55, 109-137. [CrossRef]

22. Jones, J.D.; Dangl, J.L. The plant immune system. Nature 2006, 444, 323-329. [CrossRef]

23. Medzhitov, R.; Janeway, C.A., Jr. Innate immunity: Impact on the adaptive immune response. Curr. Opin. Immunol. 1997, 9, 4-9. [CrossRef]

24. Gou, X.; Li, J. Paired receptor and coreceptor kinases perceive extracellular signals to control plant development. Plant Physiol. 2020, 182, 1667-1681. [CrossRef] [PubMed]

25. Becraft, P.W. Receptor kinase signaling in plant development. Annu. Rev. Cell Dev. Biol. 2002, 18, 163-192. [CrossRef] [PubMed]

26. Shiu, S.H.; Bleecker, A.B. Receptor-like kinases from Arabidopsis form a monophyletic gene family related to animal receptor kinases. Proc. Natl. Acad. Sci. USA 2001, 98, 10763-10768. [CrossRef]

27. Sun, Y.; Li, L.; Macho, A.P.; Han, Z.; Hu, Z.; Zipfel, C.; Zhou, J.M.; Chai, J. Structural basis for flg22-induced activation of the Arabidopsis FLS2-BAK1 immune complex. Science 2013, 342, 624-628. [CrossRef]

28. Chinchilla, D.; Bauer, Z.; Regenass, M.; Boller, T.; Felix, G. The Arabidopsis receptor kinase FLS2 binds flg22 and determines the specificity of flagellin perception. Plant Cell 2006, 18, 465-476. [CrossRef]

29. Chinchilla, D.; Zipfel, C.; Robatzek, S.; Kemmerling, B.; Nurnberger, T.; Jones, J.D.; Felix, G.; Boller, T. A flagellin-induced complex of the receptor FLS2 and BAK1 initiates plant defence. Nature 2007, 448, 497-500. [CrossRef]

30. Guo, H.; Nolan, T.M.; Song, G.; Liu, S.; Xie, Z.; Chen, J.; Schnable, P.S.; Walley, J.W.; Yin, Y. FERONIA receptor kinase contributes to plant immunity by suppressing jasmonic acid signaling in Arabidopsis thaliana. Curr. Biol. 2018, 28, 3316-3324. [CrossRef] 
31. Cao, Y.; Liang, Y.; Tanaka, K.; Nguyen, C.T.; Jedrzejczak, R.P.; Joachimiak, A.; Stacey, G. The kinase LYK5 is a major chitin receptor in Arabidopsis and forms a chitin-induced complex with related kinase CERK1. eLife 2014, 3, e03766. [CrossRef] [PubMed]

32. Espinoza, C.; Liang, Y.; Stacey, G. Chitin receptor CERK1 links salt stress and chitin-triggered innate immunity in Arabidopsis. Plant J. 2017, 89, 984-995. [CrossRef]

33. Leppyanen, I.V.; Shakhnazarova, V.Y.; Shtark, O.Y.; Vishnevskaya, N.A.; Tikhonovich, I.A.; Dolgikh, E.A. Receptor-like kinase LYK9 in Pisum sativum L. is the CERK1-like receptor that controls both plant immunity and AM symbiosis development. Int. J. Mol. Sci. 2017, 19, 8. [CrossRef] [PubMed]

34. Zhang, X.; Dong, W.; Sun, J.; Feng, F.; Deng, Y.; He, Z.; Oldroyd, G.E.; Wang, E. The receptor kinase CERK1 has dual functions in symbiosis and immunity signalling. Plant J. 2015, 81, 258-267. [CrossRef] [PubMed]

35. Singh, P.; Zimmerli, L. Lectin receptor kinases in plant innate immunity. Front. Plant Sci. 2013, 4, 124. [CrossRef]

36. Huang, P.Y.; Yeh, Y.H.; Liu, A.C.; Cheng, C.P.; Zimmerli, L. The Arabidopsis LecRK-VI.2 associates with the pattern-recognition receptor FLS2 and primes Nicotiana benthamiana pattern-triggered immunity. Plant J. 2014, 79, 243-255. [CrossRef] [PubMed]

37. Choi, J.; Tanaka, K.; Cao, Y.; Qi, Y.; Qiu, J.; Liang, Y.; Lee, S.Y.; Stacey, G. Identification of a plant receptor for extracellular ATP. Science 2014, 343, 290-294. [CrossRef] [PubMed]

38. Antolín-Llovera, M.; Ried, M.K.; Binder, A.; Parniske, M. Receptor kinase signaling pathways in plant-microbe interactions. Annu. Rev. Phytopathol. 2012, 50, 451-473. [CrossRef]

39. Zipfel, C.; Robatzek, S.; Navarro, L.; Oakeley, E.J.; Jones, J.D.; Felix, G.; Boller, T. Bacterial disease resistance in Arabidopsis through flagellin perception. Nature 2004, 428, 764-767. [CrossRef]

40. Felix, G.; Duran, J.D.; Volko, S.; Boller, T. Plants have a sensitive perception system for the most conserved domain of bacterial flagellin. Plant J. 1999, 18, 265-276. [CrossRef]

41. Navarro, L.; Zipfel, C.; Rowland, O.; Keller, I.; Robatzek, S.; Boller, T.; Jones, J.D. The transcriptional innate immune response to flg22. Interplay and overlap with Avr gene-dependent defense responses and bacterial pathogenesis. Plant Physiol. 2004, 135, 1113-1128. [CrossRef]

42. Gómez-Gómez, L.; Bauer, Z.; Boller, T. Both the extracellular leucine-rich repeat domain and the kinase activity of FLS2 are required for flagellin binding and signaling in Arabidopsis. Plant Cell 2001, 13, 1155-1163. [CrossRef] [PubMed]

43. Gómez-Gómez, L.; Boller, T. FLS2: An LRR receptor-like kinase involved in the perception of the bacterial elicitor flagellin in Arabidopsis. Mol. Cell 2000, 5, 1003-1011. [CrossRef]

44. Zeng, W.; He, S.Y. A prominent role of the flagellin receptor FLAGELLIN-SENSING2 in mediating stomatal response to Pseudomonas syringae pv tomato DC3000 in Arabidopsis. Plant Physiol. 2010, 153, 1188-1198. [CrossRef]

45. Guzel Deger, A.; Scherzer, S.; Nuhkat, M.; Kedzierska, J.; Kollist, H.; Brosché, M.; Unyayar, S.; Boudsocq, M.; Hedrich, R.; Roelfsema, M.R. Guard cell SLAC1-type anion channels mediate flagellin-induced stomatal closure. New Phytol. 2015, 208, 162-173. [CrossRef] [PubMed]

46. Li, J.; Wen, J.Q.; Lease, K.A.; Doke, J.T.; Tax, F.E.; Walker, J.C. BAK1, an Arabidopsis LRR receptor-like protein kinase, interacts with BRI1 and modulates brassinosteroid signaling. Cell 2002, 110, 213-222. [CrossRef]

47. Nam, K.H.; Li, J. BRI1/BAK1, a receptor kinase pair mediating brassinosteroid signaling. Cell 2002, 110, 203-212. [CrossRef]

48. Shang, Y.; Dai, C.; Lee, M.M.; Kwak, J.M.; Nam, K.H. BRI1-associated receptor kinase 1 regulates guard cell ABA signaling mediated by open stomata 1 in Arabidopsis. Mol. Plant. 2016, 9, 447-460. [CrossRef] [PubMed]

49. Koller, T.; Bent, A.F. FLS2-BAK1 extracellular domain interaction sites required for defense signaling activation. PLoS ONE 2014, 9, e111185. [CrossRef]

50. Liang, X.; Zhou, J.M. Receptor-like cytoplasmic kinases: Central players in plant receptor kinase-mediated signaling. Annu. Rev. Plant Biol. 2018, 69, 267-299. [CrossRef] [PubMed]

51. Shiu, S.H.; Karlowski, W.M.; Pan, R.; Tzeng, Y.H.; Mayer, K.F.; Li, W.H. Comparative analysis of the receptor-like kinase family in Arabidopsis and rice. Plant Cell 2004, 16, 1220-1234. [CrossRef]

52. Rao, S.; Zhou, Z.; Miao, P.; Bi, G.; Hu, M.; Wu, Y.; Feng, F.; Zhang, X.; Zhou, J.M. Roles of receptor-like cytoplasmic kinase VII members in pattern-triggered immune signaling. Plant Physiol. 2018, 177, 1679-1690. [CrossRef]

53. Li, L.; Li, M.; Yu, L.; Zhou, Z.; Liang, X.; Liu, Z.; Cai, G.; Gao, L.; Zhang, X.; Wang, Y.; et al. The FLS2-associated kinase BIK1 directly phosphorylates the NADPH oxidase RbohD to control plant immunity. Cell Host Microbe 2014, 15, 329-338. [CrossRef] [PubMed]

54. Boudsocq, M.; Willmann, M.R.; McCormack, M.; Lee, H.; Shan, L.; He, P.; Bush, J.; Cheng, S.H.; Sheen, J. Differential innate immune signalling via $\mathrm{Ca}^{2+}$ sensor protein kinases. Nature 2010, 464, 418-422. [CrossRef]

55. Chi, Y.; Wang, C.; Wang, M.; Wan, D.; Huang, F.; Jiang, Z.; Crawford, B.M.; Vo-Dinh, T.; Yuan, F.; Wu, F.; et al. Flg22-induced Ca ${ }^{2+}$ increases undergo desensitization and resensitization. Plant Cell Environ. 2021. [CrossRef]

56. Khokon, A.R.; Okuma, E.; Hossain, M.A.; Munemasa, S.; Uraji, M.; Nakamura, Y.; Mori, I.C.; Murata, Y. Involvement of extracellular oxidative burst in salicylic acid-induced stomatal closure in Arabidopsis. Plant Cell Environ. 2011, 34, 434-443. [CrossRef]

57. Nuhse, T.S.; Bottrill, A.R.; Jones, A.M.; Peck, S.C. Quantitative phosphoproteomic analysis of plasma membrane proteins reveals regulatory mechanisms of plant innate immune responses. Plant J. 2007, 51, 931-940. [CrossRef] 
58. Kobayashi, M.; Ohura, I.; Kawakita, K.; Yokota, N.; Fujiwara, M.; Shimamoto, K.; Doke, N.; Yoshioka, H. Calcium-dependent protein kinases regulate the production of reactive oxygen species by potato NADPH oxidase. Plant Cell 2007, 19, 1065-1080. [CrossRef] [PubMed]

59. Ogasawara, Y.; Kaya, H.; Hiraoka, G.; Yumoto, F.; Kimura, S.; Kadota, Y.; Hishinuma, H.; Senzaki, E.; Yamagoe, S.; Nagata, K.; et al. Synergistic activation of the Arabidopsis NADPH oxidase AtrbohD by Ca ${ }^{2+}$ and phosphorylation. J. Biol. Chem. 2008, 283, 8885-8892. [CrossRef]

60. Kadota, Y.; Sklenar, J.; Derbyshire, P.; Stransfeld, L.; Asai, S.; Ntoukakis, V.; Jones, J.D.; Shirasu, K.; Menke, F.; Jones, A.; et al. Direct regulation of the NADPH oxidase RBOHD by the PRR-associated kinase BIK1 during plant immunity. Mol. Cell 2014, 54, 43-55. [CrossRef] [PubMed]

61. Huang, C.; Yan, Y.; Zhao, H.; Ye, Y.; Cao, Y. Arabidopsis CPK5 phosphorylates the chitin receptor LYK5 to regulate plant innate immunity. Front. Plant Sci. 2020, 11, 702. [CrossRef]

62. Dubiella, U.; Seybold, H.; Durian, G.; Komander, E.; Lassig, R.; Witte, C.P.; Schulze, W.X.; Romeis, T. Calcium-dependent protein kinase/NADPH oxidase activation circuit is required for rapid defense signal propagation. Proc. Natl. Acad. Sci. USA 2013, 110, 8744-8749. [CrossRef]

63. Oldham, W.M.; Hamm, H.E. Heterotrimeric G protein activation by G-protein-coupled receptors. Nat. Rev. Mol. Cell Biol. 2008, 9 , 60-71. [CrossRef]

64. Coursol, S.; Fan, L.M.; Le Stunff, H.; Spiegel, S.; Gilroy, S.; Assmann, S.M. Sphingolipid signalling in Arabidopsis guard cells involves heterotrimeric $G$ proteins. Nature 2003, 423, 651-654. [CrossRef]

65. Wang, X.Q.; Ullah, H.; Jones, A.M.; Assmann, S.M. G protein regulation of ion channels and abscisic acid signaling in Arabidopsis guard cells. Science 2001, 292, 2070-2072. [CrossRef]

66. Zhang, W.; He, S.Y.; Assmann, S.M. The plant innate immunity response in stomatal guard cells invokes G-protein-dependent ion channel regulation. Plant J. 2008, 56, 984-996. [CrossRef]

67. Lee, Y.R.; Assmann, S.M. Arabidopsis thaliana 'extra-large GTP-binding protein' (AtXLG1): A new class of G-protein. Plant Mol. Biol. 1999, 40, 55-64. [CrossRef] [PubMed]

68. Liang, X.; Ding, P.; Lian, K.; Wang, J.; Ma, M.; Li, L.; Li, L.; Li, M.; Zhang, X.; Chen, S.; et al. Arabidopsis heterotrimeric G proteins regulate immunity by directly coupling to the FLS2 receptor. eLife 2016, 5, e13568. [CrossRef] [PubMed]

69. Schmidt, C.; Schroeder, J.I. Anion selectivity of slow anion channels in the plasma membrane of guard cells (large nitrate permeability). Plant Physiol. 1994, 106, 383-391. [CrossRef]

70. Pandey, S.; Zhang, W.; Assmann, S.M. Roles of ion channels and transporters in guard cell signal transduction. FEBS Lett. 2007, 581, 2325-2336. [CrossRef] [PubMed]

71. Vahisalu, T.; Kollist, H.; Wang, Y.F.; Nishimura, N.; Chan, W.Y.; Valerio, G.; Lamminmäki, A.; Brosché, M.; Moldau, H.; Desikan, R.; et al. SLAC1 is required for plant guard cell S-type anion channel function in stomatal signalling. Nature 2008, 452, 487-491. [CrossRef]

72. Geiger, D.; Scherzer, S.; Mumm, P.; Stange, A.; Marten, I.; Bauer, H.; Ache, P.; Matschi, S.; Liese, A.; Al-Rasheid, K.A.; et al. Activity of guard cell anion channel SLAC1 is controlled by drought-stress signaling kinase-phosphatase pair. Proc. Natl. Acad. Sci. USA 2009, 106, 21425-21430. [CrossRef]

73. Thor, K.; Jiang, S.; Michard, E.; George, J.; Scherzer, S.; Huang, S.; Dindas, J.; Derbyshire, P.; Leitão, N.; DeFalco, T.A.; et al. The calcium-permeable channel OSCA1.3 regulates plant stomatal immunity. Nature 2020, 585, 569-573. [CrossRef]

74. Lee, S.; Choi, H.; Suh, S.; Doo, I.S.; Oh, K.Y.; Choi, E.J.; Schroeder Taylor, A.T.; Low, P.S.; Lee, Y. Oligogalacturonic acid and chitosan reduce stomatal aperture by inducing the evolution of reactive oxygen species from guard cells of tomato and Commelina communis. Plant Physiol. 1999, 121, 147-152. [CrossRef] [PubMed]

75. Kaku, H.; Nishizawa, Y.; Ishii-Minami, N.; Akimoto-Tomiyama, C.; Dohmae, N.; Takio, K.; Minami, E.; Shibuya, N. Plant cells recognize chitin fragments for defense signaling through a plasma membrane receptor. Proc. Natl. Acad. Sci. USA 2006, 103, 11086-11091. [CrossRef] [PubMed]

76. Shinya, T.; Motoyama, N.; Ikeda, A.; Wada, M.; Kamiya, K.; Hayafune, M.; Kaku, H.; Shibuya, N. Functional characterization of CEBiP and CERK1 homologs in arabidopsis and rice reveals the presence of different chitin receptor systems in plants. Plant Cell Physiol. 2012, 53, 1696-1706. [CrossRef]

77. Miya, A.; Albert, P.; Shinya, T.; Desaki, Y.; Ichimura, K.; Shirasu, K.; Narusaka, Y.; Kawakami, N.; Kaku, H.; Shibuya, N. CERK1, a LysM receptor kinase, is essential for chitin elicitor signaling in Arabidopsis. Proc. Natl. Acad. Sci. USA 2007, 104, 19613-19618. [CrossRef]

78. Wan, J.; Zhang, X.C.; Neece, D.; Ramonell, K.M.; Clough, S.; Kim, S.Y.; Stacey, M.G.; Stacey, G. A LysM receptor-like kinase plays a critical role in chitin signaling and fungal resistance in Arabidopsis. Plant Cell 2008, 20, 471-481. [CrossRef]

79. Xue, D.X.; Li, C.L.; Xie, Z.P.; Staehelin, C. LYK4 is a component of a tripartite chitin receptor complex in Arabidopsis thaliana. J. Exp. Bot. 2019, 70, 5507-5516. [CrossRef] [PubMed]

80. Wan, J.; Tanaka, K.; Zhang, X.C.; Son, G.H.; Brechenmacher, L.; Nguyen, T.H.; Stacey, G. LYK4, a lysin motif receptor-like kinase, is important for chitin signaling and plant innate immunity in Arabidopsis. Plant Physiol. 2012, 160, 396-406. [CrossRef]

81. Yamaguchi, K.; Yamada, K.; Ishikawa, K.; Yoshimura, S.; Hayashi, N.; Uchihashi, K.; Ishihama, N.; Kishi-Kaboshi, M.; Takahashi, A.; Tsuge, S.; et al. A receptor-like cytoplasmic kinase targeted by a plant pathogen effector is directly phosphorylated by the chitin receptor and mediates rice immunity. Cell Host Microbe 2013, 13, 347-357. [CrossRef] [PubMed] 
82. Kishi-Kaboshi, M.; Okada, K.; Kurimoto, L.; Murakami, S.; Umezawa, T.; Shibuya, N.; Yamane, H.; Miyao, A.; Takatsuji, H.; Takahashi, A.; et al. A rice fungal MAMP-responsive MAPK cascade regulates metabolic flow to antimicrobial metabolite synthesis. Plant J. 2010, 63, 599-612. [CrossRef]

83. Yamada, K.; Yamaguchi, K.; Yoshimura, S.; Terauchi, A.; Kawasaki, T. Conservation of chitin-induced MAPK signaling pathways in rice and Arabidopsis. Plant Cell Physiol. 2017, 58, 993-1002. [CrossRef]

84. Shinya, T.; Yamaguchi, K.; Desaki, Y.; Yamada, K.; Narisawa, T.; Kobayashi, Y.; Maeda, K.; Suzuki, M.; Tanimoto, T.; Takeda, J.; et al. Selective regulation of the chitin-induced defense response by the Arabidopsis receptor-like cytoplasmic kinase PBL27. Plant J. 2014, 79, 56-66. [CrossRef] [PubMed]

85. Yamada, K.; Yamaguchi, K.; Shirakawa, T.; Nakagami, H.; Mine, A.; Ishikawa, K.; Fujiwara, M.; Narusaka, M.; Narusaka, Y.; Ichimura, K.; et al. The Arabidopsis CERK1-associated kinase PBL27 connects chitin perception to MAPK activation. Embo J. 2016, 35, 2468-2483. [CrossRef] [PubMed]

86. Su, J.; Zhang, M.; Zhang, L.; Sun, T.; Liu, Y.; Lukowitz, W.; Xu, J.; Zhang, S. Regulation of stomatal immunity by interdependent functions of a pathogen-responsive MPK3/MPK6 cascade and abscisic acid. Plant Cell 2017, 29, 526-542. [CrossRef] [PubMed]

87. Liu, Y.; Maierhofer, T.; Rybak, K.; Sklenar, J.; Breakspear, A.; Johnston, M.G.; Fliegmann, J.; Huang, S.; Roelfsema, M.R.G.; Felix, G.; et al. Anion channel SLAH3 is a regulatory target of chitin receptor-associated kinase PBL27 in microbial stomatal closure. eLife 2019, 8, e44474. [CrossRef]

88. Qi, J.; Wang, J.; Gong, Z.; Zhou, J.M. Apoplastic ROS signaling in plant immunity. Curr. Opin. Plant Biol. 2017, 38, 92-100. [CrossRef]

89. André, S.; Siebert, H.C.; Nishiguchi, M.; Tazaki, K.; Gabius, H.J. Evidence for lectin activity of a plant receptor-like protein kinase by application of neoglycoproteins and bioinformatic algorithms. Biochim. Biophys. Acta 2005, 1725, 222-232. [CrossRef]

90. Bouwmeester, K.; Govers, F. Arabidopsis L-type lectin receptor kinases: Phylogeny, classification, and expression profiles. J. Exp. Bot. 2009, 60, 4383-4396. [CrossRef] [PubMed]

91. Kim, S.Y.; Sivaguru, M.; Stacey, G. Extracellular ATP in plants. Visualization, localization, and analysis of physiological significance in growth and signaling. Plant Physiol. 2006, 142, 984-992. [CrossRef] [PubMed]

92. Choi, J.; Tanaka, K.; Liang, Y.; Cao, Y.; Lee, S.Y.; Stacey, G. Extracellular ATP, a danger signal, is recognized by DORN1 in Arabidopsis. Biochem. J. 2014, 463, 429-437. [CrossRef]

93. Hao, L.H.; Wang, W.X.; Chen, C.; Wang, Y.F.; Liu, T.; Li, X.; Shang, Z.L. Extracellular ATP promotes stomatal opening of Arabidopsis thaliana through heterotrimeric $\mathrm{G}$ protein $\alpha$ subunit and reactive oxygen species. Mol. Plant. 2012, 5, 852-864. [CrossRef]

94. Wang, F.; Jia, J.; Wang, Y.; Wang, W.; Chen, Y.; Liu, T.; Shang, Z. Hyperpolization-activated Ca ${ }^{2+}$ channels in guard cell plasma membrane are involved in extracellular ATP-promoted stomatal opening in Vicia faba. J. Plant Physiol. 2014, 171, 1241-1247. [CrossRef]

95. Chen, D.; Cao, Y.; Li, H.; Kim, D.; Ahsan, N.; Thelen, J.; Stacey, G. Extracellular ATP elicits DORN1-mediated RBOHD phosphorylation to regulate stomatal aperture. Nat. Commun. 2017, 8, 2265. [CrossRef]

96. Tripathi, D.; Zhang, T.; Koo, A.J.; Stacey, G.; Tanaka, K. Extracellular ATP acts on jasmonate signaling to reinforce plant defense. Plant Physiol. 2018, 176, 511-523. [CrossRef]

97. Tanaka, K.; Gilroy, S.; Jones, A.M.; Stacey, G. Extracellular ATP signaling in plants. Trends Cell Biol. 2010, 20, 601-608. [CrossRef]

98. Galione, A.; Churchill, G.C. Cyclic ADP ribose as a calcium-mobilizing messenger. Sci. STKE 2000, 2000, pe1. [CrossRef] [PubMed]

99. Hunt, L.; Lerner, F.; Ziegler, M. NAD—New roles in signalling and gene regulation in plants. New Phytol. 2004, 163, 31-44. [CrossRef] [PubMed]

100. Ziegler, M. A vital link between energy and signal transduction. FEBS J. 2005, 272, 4561-4564. [CrossRef] [PubMed]

101. Wang, C.; Zhou, M.; Zhang, X.; Yao, J.; Zhang, Y.; Mou, Z. A lectin receptor kinase as a potential sensor for extracellular nicotinamide adenine dinucleotide in Arabidopsis thaliana. eLife 2017, 6, e25474. [CrossRef]

102. Zhang, X.; Mou, Z. Extracellular pyridine nucleotides induce PR gene expression and disease resistance in Arabidopsis. Plant J. 2009, 57, 302-312. [CrossRef] [PubMed]

103. Wang, C.; Huang, X.; Li, Q.; Zhang, Y.; Li, J.L.; Mou, Z. Extracellular pyridine nucleotides trigger plant systemic immunity through a lectin receptor kinase/BAK1 complex. Nat. Commun. 2019, 10, 4810. [CrossRef] [PubMed]

104. Singh, P.; Kuo, Y.C.; Mishra, S.; Tsai, C.H.; Chien, C.C.; Chen, C.W.; Desclos-Theveniau, M.; Chu, P.W.; Schulze, B.; Chinchilla, D.; et al. The lectin receptor kinase-VI.2 is required for priming and positively regulates Arabidopsis pattern-triggered immunity. Plant Cell 2012, 24, 1256-1270. [CrossRef] [PubMed]

105. Desclos-Theveniau, M.; Arnaud, D.; Huang, T.Y.; Lin, G.J.; Chen, W.Y.; Lin, Y.C.; Zimmerli, L. The Arabidopsis lectin receptor kinase LecRK-V.5 represses stomatal immunity induced by Pseudomonas syringae pv. tomato DC3000. PLoS Pathog. 2012, 8 , e1002513. [CrossRef]

106. Yekondi, S.; Liang, F.C.; Okuma, E.; Radziejwoski, A.; Mai, H.W.; Swain, S.; Singh, P.; Gauthier, M.; Chien, H.C.; Murata, Y.; et al. Nonredundant functions of Arabidopsis LecRK-V.2 and LecRK-VII.1 in controlling stomatal immunity and jasmonate-mediated stomatal closure. New Phytol. 2018, 218, 253-268. [CrossRef] [PubMed]

107. Wan, J.; Patel, A.; Mathieu, M.; Kim, S.Y.; Xu, D.; Stacey, G. A lectin receptor-like kinase is required for pollen development in Arabidopsis. Plant Mol. Biol. 2008, 67, 469-482. [CrossRef] 
108. Xiao, W.; Hu, S.; Zou, X.; Cai, R.; Liao, R.; Lin, X.; Yao, R.; Guo, X. Lectin receptor-like kinase LecRK-VIII.2 is a missing link in MAPK signaling-mediated yield control. Plant Physiol. 2021, 187, 303-320. [CrossRef] [PubMed]

109. Bouwmeester, K.; de Sain, M.; Weide, R.; Gouget, A.; Klamer, S.; Canut, H.; Govers, F. The lectin receptor kinase LecRK-I.9 is a novel Phytophthora resistance component and a potential host target for a RXLR effector. PLoS Pathog. 2011, 7, e1001327. [CrossRef]

110. Djami-Tchatchou, A.T.; Dubery, I.A. miR393 regulation of lectin receptor-like kinases associated with LPS perception in Arabidopsis thaliana. Biochem. Biophys. Res. Commun. 2019, 513, 88-92. [CrossRef]

111. Boisson-Dernier, A.; Kessler, S.A.; Grossniklaus, U. The walls have ears: The role of plant CrRLK1Ls in sensing and transducing extracellular signals. J. Exp. Bot. 2011, 62, 1581-1591. [CrossRef]

112. Franck, C.M.; Westermann, J.; Boisson-Dernier, A. Plant malectin-like receptor kinases: From cell wall integrity to immunity and beyond. Annu. Rev. Plant Biol. 2018, 69, 301-328. [CrossRef]

113. Duan, Q.; Liu, M.J.; Kita, D.; Jordan, S.S.; Yeh, F.J.; Yvon, R.; Carpenter, H.; Federico, A.N.; Garcia-Valencia, L.E.; Eyles, S.J.; et al. FERONIA controls pectin- and nitric oxide-mediated male-female interaction. Nature 2020, 579, 561-566. [CrossRef]

114. Escobar-Restrepo, J.M.; Huck, N.; Kessler, S.; Gagliardini, V.; Gheyselinck, J.; Yang, W.C.; Grossniklaus, U. The FERONIA receptor-like kinase mediates male-female interactions during pollen tube reception. Science 2007, 317, 656-660. [CrossRef]

115. Wang, L.; Yang, T.; Wang, B.Q.; Lin, Q.L.; Zhu, S.R.; Li, C.Y.; Ma, Y.C.; Tang, J.; Xing, J.J.; Li, X.S.; et al. RALF1-FERONIA complex affects splicing dynamics to modulate stress responses and growth in plants. Sci. Adv. 2020, 6, eaaz1622. [CrossRef] [PubMed]

116. Zhu, S.R.; Estévez, J.M.; Liao, H.D.; Zhu, Y.H.; Yang, T.; Li, C.Y.; Wang, Y.C.; Li, L.; Liu, X.M.; Pacheco, J.M.; et al. The RALF1FERONIA complex phosphorylates eIF4E1 to promote protein synthesis and polar root hair growth. Mol. Plant. 2020, 13, 698-716. [CrossRef]

117. Keinath, N.F.; Kierszniowska, S.; Lorek, J.; Bourdais, G.; Kessler, S.A.; Shimosato-Asano, H.; Grossniklaus, U.; Schulze, W.X.; Robatzek, S.; Panstruga, R. PAMP (pathogen-associated molecular pattern)-induced changes in plasma membrane compartmentalization reveal novel components of plant immunity. J. Biol. Chem. 2010, 285, 39140-39149. [CrossRef] [PubMed]

118. Haruta, M.; Sabat, G.; Stecker, K.; Minkoff, B.B.; Sussman, M.R. A peptide hormone and its receptor protein kinase regulate plant cell expansion. Science 2014, 343, 408-411. [CrossRef]

119. Stegmann, M.; Monaghan, J.; Smakowska-Luzan, E.; Rovenich, H.; Lehner, A.; Holton, N.; Belkhadir, Y.; Zipfel, C. The receptor kinase FER is a RALF-regulated scaffold controlling plant immune signaling. Science 2017, 355, 287-289. [CrossRef] [PubMed]

120. Carlton, W.M.; Braun, E.J.; Gleason, M.L. Ingress of Clavibacter michiganensis subsp. michiganensis into tomato leaves through hydathodes. Phytopathology 1998, 88, 525-529. [CrossRef]

121. Beattie, G.A.; Lindow, S.E. The secret life of foliar bacterial pathogens on leaves. Annu. Rev. Phytopathol. 1995, 33, 145-172. [CrossRef] [PubMed]

122. Antolín-Llovera, M.; Petutsching, E.K.; Ried, M.K.; Lipka, V.; Nürnberger, T.; Robatzek, S.; Parniske, M. Knowing your friends and foes-plant receptor-like kinases as initiators of symbiosis or defence. New Phytol. 2014, 204, 791-802. [CrossRef]

123. Melotto, M.; Underwood, W.; He, S.Y. Role of stomata in plant innate immunity and foliar bacterial diseases. Annu. Rev. Phytopathol. 2008, 46, 101-122. [CrossRef]

124. Sierla, M.; Horak, H.; Overmyer, K.; Waszczak, C.; Yarmolinsky, D.; Maierhofer, T.; Vainonen, J.P.; Salojarvi, J.; Denessiouk, K.; Laanemets, K.; et al. The receptor-like pseudokinase GHR1 is required for stomatal closure. Plant Cell 2018, 30, $2813-2837$. [CrossRef] [PubMed]

125. Hua, D.; Wang, C.; He, J.; Liao, H.; Duan, Y.; Zhu, Z.; Guo, Y.; Chen, Z.; Gong, Z. A plasma membrane receptor kinase, GHR1, mediates abscisic acid- and hydrogen peroxide-regulated stomatal movement in Arabidopsis. Plant Cell 2012, $24,2546-2561$. [CrossRef] [PubMed]

126. Hussan, R.H.; Dubery, I.A.; Piater, L.A. Identification of MAMP-responsive plasma membrane-associated proteins in Arabidopsis thaliana following challenge with different LPS chemotypes from Xanthomonas campestris. Pathogens 2020, 9, 787. [CrossRef]

127. Isner, J.C.; Begum, A.; Nuehse, T.; Hetherington, A.M.; Maathuis, F.J.M. KIN7 kinase regulates the vacuolar TPK1 K ${ }^{+}$channel during stomatal closure. Curr. Biol. 2018, 28, 466-472. [CrossRef]

128. Shang, Y.; Yang, D.; Ha, Y.; Shin, H.Y.; Nam, K.H. Receptor-like protein kinases RPK1 and BAK1 sequentially form complexes with the cytoplasmic kinase OST1 to regulate ABA-induced stomatal closure. J. Exp. Bot. 2020, 71, 1491-1502. [CrossRef]

129. Chan, C.; Panzeri, D.; Okuma, E.; Toldsepp, K.; Wang, Y.Y.; Louh, G.Y.; Chin, T.C.; Yeh, Y.H.; Yeh, H.L.; Yekondi, S.; et al. STRESS INDUCED FACTOR 2 regulates Arabidopsis stomatal immunity through phosphorylation of the anion channel SLAC1. Plant Cell 2020, 32, 2216-2236. [CrossRef]

130. Asai, T.; Tena, G.; Plotnikova, J.; Willmann, M.R.; Chiu, W.L.; Gomez-Gomez, L.; Boller, T.; Ausubel, F.M.; Sheen, J. MAP kinase signalling cascade in Arabidopsis innate immunity. Nature 2002, 415, 977-983. [CrossRef]

131. Gao, M.; Liu, J.; Bi, D.; Zhang, Z.; Cheng, F.; Chen, S.; Zhang, Y. MEKK1, MKK1/MKK2 and MPK4 function together in a mitogen-activated protein kinase cascade to regulate innate immunity in plants. Cell Res. 2008, 18, 1190-1198. [CrossRef]

132. Suarez-Rodriguez, M.C.; Adams-Phillips, L.; Liu, Y.; Wang, H.; Su, S.H.; Jester, P.J.; Zhang, S.; Bent, A.F.; Krysan, P.J. MEKK1 is required for flg22-induced MPK4 activation in Arabidopsis plants. Plant Physiol. 2007, 143, 661-669. [CrossRef] [PubMed]

133. Gudesblat, G.E.; Iusem, N.D.; Morris, P.C. Guard cell-specific inhibition of Arabidopsis MPK3 expression causes abnormal stomatal responses to abscisic acid and hydrogen peroxide. New Phytol. 2007, 173, 713-721. [CrossRef] [PubMed] 
134. Zou, M.; Guo, M.; Zhou, Z.; Wang, B.; Pan, Q.; Li, J.; Zhou, J.M.; Li, J. MPK3- and MPK6-mediated VLN3 phosphorylation regulates actin dynamics during stomatal immunity in Arabidopsis. Nat. Commun. 2021, 12, 6474. [CrossRef]

135. Hajný, J.; Prát, T.; Rydza, N.; Rodriguez, L.; Tan, S.; Verstraeten, I.; Domjan, D.; Mazur, E.; Smakowska-Luzan, E.; Smet, W.; et al. Receptor kinase module targets PIN-dependent auxin transport during canalization. Science 2020, 370, 550-557. [CrossRef] [PubMed]

136. Tian, W.; Hou, C.; Ren, Z.; Wang, C.; Zhao, F.; Dahlbeck, D.; Hu, S.; Zhang, L.; Niu, Q.; Li, L.; et al. A calmodulin-gated calcium channel links pathogen patterns to plant immunity. Nature 2019, 572, 131-135. [CrossRef]

137. Qi, J.; Song, C.P.; Wang, B.; Zhou, J.; Kangasjarvi, J.; Zhu, J.K.; Gong, Z. Reactive oxygen species signaling and stomatal movement in plant responses to drought stress and pathogen attack. J. Integr. Plant Biol. 2018, 60, 805-826. [CrossRef]

138. Panchal, S.; Melotto, M. Stomate-based defense and environmental cues. Plant Signal. Behav. 2017, 12, e1362517. [CrossRef]

139. Hsu, P.K.; Takahashi, Y.; Merilo, E.; Costa, A.; Zhang, L.; Kernig, K.; Lee, K.H.; Schroeder, J.I. Raf-like kinases and receptor-like (pseudo) kinase GHR1 are required for stomatal vapor pressure difference response. Proc. Natl. Acad. Sci. USA 2021, 118. [CrossRef] 